\title{
EFFECTS OF INNOVATION ON EMPLOYMENT: A DYNAMIC PANEL ANALYSIS
}

\author{
STEFAN LACHENMAIER \\ HORST ROTTMANN
}

CESIFO WORKING PAPER No. 2015

CATEGORY 9: INDUSTRIAL ORGANISATION

JUNE 2007

An electronic version of the paper may be downloaded

- from the SSRN website:

- from the RePEc website:

www.SSRN.com

- from the CESifo website:

www.RePEc.org

www.CESifo-group.de 


\title{
EFFECTS OF INNOVATION ON EMPLOYMENT: A DYNAMIC PANEL ANALYSIS
}

\begin{abstract}
This paper estimates the effect of innovation on employment at the firm level. Our uniquely long innovation panel data set of German manufacturing firms covers more than 20 years and allows us to use various innovation measures. We can distinguish between product and process innovations as well as between innovation inputs and innovation outputs. Using dynamic panel GMM system estimation we find positive effects of innovation on employment. This result is robust to the use of product and process innovations as well as for innovation input and output.
\end{abstract}

JEL Code: O30, L60, C23, J23.

Keywords: innovation, employment, panel data, dynamic panel methods.

Stefan Lachenmaier

Ifo Institute for Economic Research at the University of Munich

Poschingerstr. 5

81679 Munich

Germany

lachenmaier@ifo.de
Horst Rottmann

University of Applied Sciences

Amberg-Weiden

Hetzenrichter Weg 15

92637 Weiden

Germany

h.rottmann@fh-amberg-weiden.de

The authors gratefully acknowledge financial support from the "Deutsche Forschungsgemeinschaft" for this project and thank the participants of the "5th Annual International Industrial Organization Conference" in Savannah, USA and the "Ifo Workshop on the Maintenance and Analysis of Micro Data" in Munich, Germany for valuable comments and suggestions. 


\section{Introduction}

\subsection{The Issue}

This paper estimates the effect of innovation on employment at the firm level using a dynamic panel approach. The direction of this effect remains unclear in theoretical analyses and calls for an empirical approach. Using a uniquely rich dataset for German manufacturing firms for the years 1982-2002 our estimation method allows us to control for unobserved firm heterogeneity, for possible endogeneity of the innovation measures with respect to employment and for potential dynamic effects.

Theoretical contributions analyzing the effect of innovation on employment at the firm level stress the importance of a distinction between product and process innovations. ${ }^{1}$ But for both types of innovation, the overall effects on the labor demand of a firm are not clear. Product innovations lead to new products on the market which stimulate a new demand. This increasing demand allows innovating firms to hire more workers. Thus, from the direct effect of product innovations on employment we would expect a positive relationship.

But there is also a less obvious indirect effect: If a firm introduces a product which is new to the market, there are no direct competitors yet and thus the innovating firm profits from a temporary monopoly position until other firms introduce similar or better products. In this market position the firm can exploit its monopoly power and maximize its profits. This can lead to a reduction in output and thus to a reduction in employment. Especially, if the new products are substitutes for existing products of the firm, the effect is not clear. New workers could simply replace old workers. Even a decrease is possible if the production of the new products requires fewer workers than the production of the old products. This effect is in the opposite direction to the direct effect. Thus, the overall effect of product innovations on employment is unclear in theory.

For process innovations the direct effect is very obvious. A process innovation is an improvement in the production process, which aims at improving the productivity of inputs, e. g. labor. So the firm is able to produce the same level of output with less workers. Considering only this argument, we would therefore expect a negative effect of process innovations on employment. But one also has to consider an important indirect effect here. The firm can produce its output at lower costs after the implementation of the process innovation. If the firm passes on this cost advantage to the price of the output good 
the demand for this good should increase and this increased output allows the firm to hire additional workers. This effect might outweigh the productivity effect and therefore it is not possible to draw a definite conclusion about the direction of the effect of process innovations on labor demand.

\subsection{Previous Empirical Literature}

These unclear results from theory are the reason why much empirical work was done to analyze the effects of innovation on employment at the firm level. Another strand of literature deals with the same question on the industry or macro level. But, in this study we want to concentrate our analysis on the firm level. A detailed overview of the existing literature is given Chennels and Van Reenen (2002).

First studies are, due to data availability, mostly cross-sectional analyses. Entorf and Pohlmeier (1990) and Zimmermann (1991) analyze German micro data. Entorf and Pohlmeier (1990) find a positive effect for product innovations, while process innovations show no significant effects. Zimmermann (1991) concludes that technological progress was important for the employment decrease in 1980, i.e. he finds a negative effect of innovation. But the definition of innovation he uses refers to a question which asks explicitly for the implementation of labor-saving technological progress. Blanchflower and Burgess (1999), however, find a positive relation between process innovation and employment growth using innovation surveys from the UK in 1990 and Australia in 1989/1990.

Newer studies use two or more points in time, which allow the authors to analyze growth rates, a methodology which eliminates the unobserved firm heterogeneity. Brouwer et al. (1993) use two innovation surveys for the Netherlands to estimate the effects of innovation on employment growth rates. They find a negative effect for overall $R \& D$ investments, but a positive effect for product-related R\&D. Greenan and Guellec (2000) use a French innovation survey of 1991 for analyzing employment growth during the period 1986 to 1990 . They find positive effects of both process and product innovation with the effect for product innovations being higher.

Recent studies that use the harmonized European innovation survey - the Community Innovation Survey (CIS) - are also in this line of analyzing employment growth rates. With this survey comparable innovation data for different countries are available. Using these data sets, there exist single country studies, e.g. Jaumandreu (2003) using Spanish

\footnotetext{
${ }^{1}$ See e.g. Katsoulacos (1986), Stoneman (1983), Hamermesh (1993), or for an overview Petit (1995).
} 
data, Peters (2004) using German data, but there also exist comparative studies like Harrison et al. (2005). Jaumandreu (2003) develops a specific model for the analysis of CIS data. Using Spanish CIS3 data of the year 2001 he finds that process innovations are not responsible for net employment displacement and that product innovations lead to a positive employment growth. Peters (2004) employs this model for Germany, extending the research to the service sector. For the manufacturing sector, she also finds positive effects of product innovations, where there is no significant difference in the size of the effect between products new to the market or products imitated by the innovating firm. For process innovations, Peters finds a negative effect on employment growth, mainly for rationalization innovations. Harrison et al. (2005) compare CIS3 data for France, Germany, Spain and the UK. Overall, the effects in the countries are quite similar. The results show again positive effects of product innovation on employment growth and show that displacement and compensation effects of process innovations are present in the manufacturing sector.

With the increasing availability of innovation data panel studies were undertaken more often. Smolny (1998) analyzes the relationship of innovation, prices and employment for Germany. He finds positive effects of product as well as process innovations on employment. Lachenmaier and Rottmann (2006) use a static panel approach and also find significantly positive effects for both types of innovation.

The studies most relevant for our work are van Reenen (1997), Rottmann and Ruschinski (1998) and Piva and Vivarelli (2004, 2005), as they allow for an adjustment process by including lagged values of employment and innovation. Rottmann and Ruschinksi (1998) use the Ifo Business Survey of the years 1980 to 1992. Using an Anderson-Hsiao dynamic panel approach the authors find positive effects of product innovation, but no significant effect for process innovations. Van Reenen (1997) analyzes UK data matched with major innovations counted by the Science and Technology Policy Research Unit (SPRU). Controlling for fixed effects, dynamics and endogeneity he finds a positive causal effect of product innovations on employment. Unfortunately, his selection of firms is restricted to firms listed at the London stock exchange. In addition, his measure of innovation differs from ours, as the SPRU innovation counts refer only to the major, most influencing innovations and do not measure small innovative progress. A similar model is estimated by Piva and Vivarelli $(2004,2005)$ for Italy using gross innovative investment as innovation measure. Using GMM system estimations they find small but significantly positive employment effects of technological change. 


\subsection{Contribution}

To sum up, most studies find a positive relationship between product innovations and employment whereas the analysis of process innovations leads to different results in the literature. We will contribute to the existing literature by using a dynamic panel framework for a uniquely long innovation data set with different innovation measures for the German manufacturing sector. As the most recent studies, we control for unobserved heterogeneity, the possible endogeneity of the innovation variable and for dynamic effects in the employment adjustment process. In addition, we have very detailed information about the innovations introduced. We can distinguish between input (innovation expenditure) and output (innovations introduced) variables of the innovation process for this long period. The innovation output variable can be split up further to distinguish between process and product innovations and to distinguish between different levels of importance of innovations. The paper is structured as follows. Section 2 presents the model and our estimation method. In Section 3 we describe the database. The results are presented in Section 4, Section 5 concludes.

\section{Econometric Modeling}

\subsection{The Employment Demand Equation}

We start our econometric modeling with a standard static employment equation.

$n_{i, t}=\beta_{1}^{\prime} X_{i, t}+\gamma_{i}+\varepsilon_{i, t} \quad$ with $\quad i=1, \ldots, N$, and $t=1, \ldots, T$

$n_{i, t}$ denotes the logarithm of the employment level of firm $i$ at time $t, X$ is a set of variables that determines employment and - in our analysis - includes for example innovation variables. $\gamma_{i}$ is an unobserved firm-specific time-invariant effect which may be correlated with the variables in $X . \varepsilon_{i, t}$ is the error term with $\varepsilon_{i, t} \sim \operatorname{iid}\left(0, \sigma_{\varepsilon}^{2}\right)$. However, a static estimation equation might lead to some problems. The high costs of hiring and firing are a well-known argument for costly employment adjustment, especially in European economies. If a firm faces these high costs, the actual employment will deviate from the equilibrium level in the short run. The short-run dynamics compound influences from adjustment costs, expectation formation and decision processes. Therefore, a dynamic 
panel data model is considered that includes unrestricted lag structures in order to model the sluggish adjustment. ${ }^{2}$

$$
c(L) n_{i, t}=\beta^{\prime}(L) X_{i, t}+\gamma_{i}+\varepsilon_{i, t},
$$

Here $c(L)$ denotes the corresponding polynomial in the lag operator for $n_{i, t} \cdot{ }^{3}$ We also include lagged values of the innovation variables to account for a time lag between the implementation of an innovation and its effect on employment. Therefore $\beta(L)$ is a vector of associated polynomials in the lag operator for the vector $X_{i, t}$.

This estimation approach then leads to the following estimation equation. We already include in this equation the respective numbers of lags that were suggested by test statistics during the estimation process.

$$
n_{i t}=\beta_{1} n_{i, t-1}+\beta_{2} n_{i, t-2}+\beta_{3} I_{i t}^{P d}+\beta_{4} I_{i, t-1}^{P d}+\beta_{5} I_{i, t-2}^{P d}+\beta_{6} I_{i t}^{P c}+\beta_{7} I_{i, t-1}^{P c}+\beta_{8} I_{i, t-2}^{P c}+\beta_{9} w_{i t}+\beta_{10} d_{i t}+\gamma_{i}+\varepsilon_{i t}
$$

Our base specification includes contemporaneous values and two lags of employment $n$, product innovation $I^{P d}$ and process innovation $I^{P d}$. Additionally, we include several control variables. In the specification above we include continuous control variables at the industry level. We control for the average industry-wide real hourly wage rate $w$ and for the industry-level Gross Value Added $d$ which is included as a proxy variable for the demand situation in the respective industry. In other specifications we use simple dummy variables for the NACE 2-digit industries and years or combinations of dummy and continuous variables.

\subsection{Estimation Approach}

The next question is how to estimate Equation (3). Simple OLS estimation of this dynamic model will lead to biased results in the presence of unobserved heterogeneity. The lagged dependent variables are correlated with $\gamma_{i}$. One can show that the OLS estimates for the lagged dependent variables are biased upwards. To eliminate these firm effects $\gamma_{i}$ the standard approach is to use the within estimator (often called fixed-effects estimator). This estimation strategy uses the demeaned estimation equation. But, the transformed variables $\left(n_{i, t-1}-\bar{n}_{i, t-1}\right)$, where $\bar{n}_{i, t-1}=\frac{1}{(T-1)} \sum_{t=2}^{T} n_{i, t-1}$, will still be negatively correlated with

\footnotetext{
${ }^{2}$ See Baltagi (2005) for a introduction of the econometrics of dynamic single equation panel data models.

${ }^{3}$ For stability of the dynamic equation the inverses of all roots of the lag operator polynomial $c(L)$ must be inside the unit circle.
} 
$\left(\varepsilon_{i, t}-\bar{\varepsilon}_{i, t}\right)$. This leads to a downward bias of the estimated parameters of the lagged dependent variables, even if the $\varepsilon_{i, t}$ are not serially correlated. Including more regressors does not remove the bias. Only if $T \rightarrow \infty$ the within-estimator will be consistent for the dynamic panel data model. However, $\mathrm{T}$ is typically small in micro panel data sets. ${ }^{4}$

For this reason one uses the first-differenced equation to eliminate the firm fixed effect. After this transformation there are instruments for the lagged differenced dependent variable $\left(\Delta n_{i, t-1}\right)$ available to avoid the correlation with the error term. There exist various suggestions for such estimators, which differ in the set of instruments used. The estimator proposed by Anderson and Hsiao (1982) uses one further lag (either as level $n_{i, t-2}$ or as difference $\Delta n_{i, t-2}$ ) as instrument for $\Delta n_{i, t-1}$. Holtz-Eakin et al. (1988) and Arellano and Bond (1991) replace the IV estimation technique by GMM estimation, in which the instrument matrix includes all (or at least more) previous level values of the lagged dependent variable. This is why this strategy is also called GMM difference estimation.

The strategy we will use in our study is known as GMM system estimation and was proposed by Blundell and Bond (1998). The authors have shown in Monte Carlo studies that this estimator behaves better than the GMM difference estimator especially in two cases: First, in short sample periods, and second, and more important for our study, it behaves better if the variables are persistent over time. If the evolution of a variable is highly persistent, the correlation between the variable in differences and its past values in levels will disappear. Therefore the instruments will be weak. In these cases the GMM difference estimator for the lagged dependent variable is also biased downwards, in the same direction as the within group estimator.

The GMM system estimator extends the model by using moment restrictions of a simultaneous system of first-differenced equations and the equations in levels. In the firstdifferenced equations one uses the lagged level values of the variables as instruments like in the GMM difference estimator. In the levels equations one uses differences as instruments. Blundell and Bond (1998) have shown, that a mild additional stationarity assumption on the initial condition allows the use of these instruments. ${ }^{5}$ Since the moments used in the GMM difference approach are a strict subset of the instruments used in the GMM system estimation, the validity of the additional instruments can be tested by a Sargan difference test (Blundell and Bond 1998).

\footnotetext{
${ }^{4}$ See e.g. Hsiao (2003), ch. 4.

${ }^{5}$ As instrument for the lagged dependent variable $n_{i, t-1}$ one can use $\Delta n_{i, t-1}$
} 
It has been shown that the two-step estimates of the GMM difference and GMM system standard errors have a downward bias. Therefore we apply the finite-sample correction for the asymptotic variance of the two-step GMM estimator (Windmeijer 2005).

Knowing the direction of the biases in the OLS estimator, the within groups estimator and the Arellano-Bond estimator, these regression methods give us upper and lower bounds of the range where we would expect the estimation coefficient to lie. As we will show in our results section after the description of the database this is also true in our study.

This estimator also allows us to address the problem of potential endogeneity of innovation. Since we measure employment and innovation both at the firm level, it is very likely that these variables are chosen simultaneously. Thus we would not estimate the causal effect in simple estimation methods. In dynamic panel estimations, however, one can also instrument the potential endogenous variables. This is done, similar to the lagged dependent variable, by using the appropriate lags as instruments of the variables. In general, if $x_{i, t}$ is endogenous, $x_{i, t-2}$ and earlier realizations of $x_{i}$ are available as valid instruments for $\Delta x_{i, t}$ in the first-differenced equation and $\Delta x_{i, t-1}$ and earlier realizations of $\Delta x_{i, t}$ are available as instruments in the level equation for $x_{i, t}$ If $x_{i, t}$ is predetermined, we can additionally use $x_{i, t-1}$ as valid instrument in the level equation and $\Delta x_{i, t}$ as valid instrument in the level equation.

\section{Database and Descriptive Statistics}

\subsection{The Ifo Innovation Survey}

For our analysis we use survey data stemming from the Ifo Innovation Survey, a survey which is conducted yearly by the Ifo Institute for Economic Research in Munich, Germany. This survey covers the German manufacturing sector. The uniqueness of this data set is the very long time horizon for which detailed innovation data is available. The survey was started in 1982, in 1991 - after the German reunification - firms from former East Germany were included and the survey is still ongoing. For this paper we use the data up to the survey of the year 2003, which describes firms' behavior in $2002 .{ }^{6}$

Each year information of in average 1500 respondents is collected. Most questions in the questionnaire are related to the innovation behavior in the preceding year. The

\footnotetext{
6 More detailed information about the history and the methodology of the Ifo Innovation Survey can be found in Penzkofer (2004).
} 
discussion of how to measure innovations correctly is still ongoing. In the "Oslo Manual" - an innovation survey manual published by the OECD and Eurostat - the importance of using both innovation input and innovation output measures is stressed (OECD and Eurostat 2005). With the Ifo Innovation Survey we can deal with both types of innovation measures: First, we can use questions whether any innovations were introduced and how important they are. Second, we can use the innovation expenditure which reflects the input to the innovation process. ${ }^{7}$

Our first measure is the question of whether any product innovations were introduced to the market or whether any process innovations were implemented in the production process. In addition we can obtain further information on the importance of an innovation. One question refers to whether the implemented innovations required R\&D. Another category of importance are those innovations for which any patent applications were filed during the innovation process. Patent applications are very expensive and so we expect that they are filed only for few important innovations, for which the firms expect high returns.

Our second measure - innovation expenditure - includes all R\&D expenses of the innovation process but also costs for licenses, patenting and other costs that emerged during the implementation of new products or processes. It is measured as the share of innovation expenditure in total sales of a firm.

In addition to the detailed innovation measures the survey collects information about other firm characteristics. An important information, which we will use as the dependent variable in the regression analyses, is the number of employees in a firm. Unfortunately the data set does not contain additional information on whether these workers are full-time or part-time workers or how many hours they work.

Since we expect the effects to differ between different industries we can also use the industry classification in the questionnaire, which can be classified according to the NACE 2-digit level. By using these control variables and the additional use of year dummy variables we also try to control for much of the variation in working hours. We thus control for an overall trend towards or away from one type, but also for differences in the structure of workers between industries.

Unfortunately, we do not get any information about wages in the firms. But, to be able to control for the variation in wages we include the real hourly wage rate within a 2-digit industry as we can obtain this information from the National Statistical Office as the best

7 A more detailed comparison of the innovation measures of the Ifo Innovation Survey with other common innovation measures can be found in Lachenmaier and Wößmann (2006). 
approximation. Also from this source we take the Gross Value Added (GVA) within a 2digit industry. This can serve as a proxy for the demand situation in the respective industry.

\subsection{Descriptive Statistics}

We use the Ifo Innovation Surveys of the years 1983-2003, containing information about firms' behavior in the years 1982-2002. The survey covers the German manufacturing sector. Merging all available yearly datasets leads to a complete sample of 31,885 observations from 6,817 firms. For our estimation strategy, which includes lagged variables and earlier values as instruments, we need at least four consecutive observations of a firm. For the correct calculation of the test statistics, however, we need six consecutive observations.

Dropping firms with less than six consecutive observations and dropping firms with missing values in the variables of interest reduces our estimation sample to 7,536 observations from 1,073 different firms. This might raise some concern about the representativeness of our sample. Table A1 in the Appendix shows descriptive statistics for the original sample and our estimation sample finally used. We see differences mainly for the employment and the innovation input variable. It seems that larger firms, which spend more on innovation tend to stay in the sample more often, what is reflected in the larger mean values in the estimation sample. As can be seen in Table A1 the average firm in our sample has a size of 654 employees. This number is driven heavily by the few very large firms, as the median firm in our sample has 129 employees. In contrast, when looking at the $25 \%$ percentile, the median and the $75 \%$ percentile we see smaller differences between the two samples. Therefore, we crosscheck all following estimations with a restricted sample excluding extreme outliers. This restricted sample, which excludes the lowest and the largest percentile of firms in terms of employees, shows an average value of 311 employees. Table A2 in the Appendix shows the distribution of the firms across different industries and size classes. The table compares the estimation sample with the original sample from the Ifo Innovation Survey. As we can see all industries and size classes are covered in our study.

Looking at the innovation variables in Table 1 we can use several questions of the Ifo Innovation Survey as innovation measures as described in Section 3.1. The most simple one is the question whether the firm introduced any innovations during the preceding year. In our sample this was the case in $51.3 \%$ of all observations. Distinguishing between product and process innovations we see that more firms introduced product innovations 
$(42 \%)$ than process innovations $(33.5 \%){ }^{8}$ Allowing for differences in the importance of innovations the number of innovators reduces. Only $34.8 \%$ of the respondents indicated the introduction of a new product for which R\&D was necessary and only $22 \%$ reported a process innovation which required R\&D. $19.6 \%$ of the respondents reported that a patent application went along with a product innovation and only $2.6 \%$ reported a process innovation with patent application. This very low number has to be kept in mind when interpreting the estimation results later.

Table 1: Descriptive Statistics

\begin{tabular}{l|ccc|cc}
\hline \hline Variable & Obs & Mean & Std. Dev. & Min & Max \\
\hline \hline Employment & 7,536 & 654 & 4,317 & 1 & 99,999 \\
Log Employment & 7,536 & 4.870 & 1.553 & 0 & 11.513 \\
\hline Innovation & 7,536 & 0.513 & & 0 & 1 \\
Product Innovation & 7,536 & 0.420 & & 0 & 1 \\
Process Innovation & 7,536 & 0.335 & & 0 & 1 \\
Product Innovation (R\&D) & 7,475 & 0.348 & & 0 & 1 \\
Process Innovation (R\&D) & 7,337 & 0.220 & & 0 & 1 \\
Product Innovation (Patents) & 7,475 & 0.196 & & 0 & 1 \\
Process Innovation (Patents) & 7,337 & 0.026 & & 0 & 1 \\
Innovation Expenditure (dummy) & 4,448 & 0.473 & & 0 & 1 \\
Innovation Expenditure (in 1000 $€$ ) & 4,448 & 8,883 & 107,645 & 0 & $2,601,066$ \\
\hline Log Sectoral Gross Value Added & 7,536 & 4.546 & 0.130 & 3.457 & 5.382 \\
Log Sectoral Real Hourly Wage Rate & 7,536 & 2.938 & 0.778 & -0.083 & 4.157 \\
\hline \hline
\end{tabular}

For the innovation expenditure we had to reduce our sample because firms are very reluctant in answering this question. Since we need again six consecutive observations for a firm without missing values in the innovation variable, our sample is reduced to 4,448 observations from 690 different firms. We create two different variables for the innovation expenditure. One is a simple indicator of whether the firm reported any positive innovation expenditure at all for a certain year, the second are the real innovation expenses. ${ }^{9} 47.3 \%$ of

\footnotetext{
${ }^{8}$ We use a non-exclusive definition of product and process innovation in this paper. We only focus on whether one of the two types of innovation was introduced, where it is not important whether the second type was also introduced. The alternative would be a distinction between non-innovators, product innovators only, process innovators only and innovators which introduced both types.

${ }^{9}$ Real values are calculated using an industry specific deflator. From the German Statistical Office, Gross Value Added is available in current and constant prices on industry level. We use this information for the construction of the deflator.
} 
the respondents reported positive innovation expenditure. The mean of the innovation expenses is about 9 million Euros.

Table 2: Descriptive Statistics According to Innovation Status

\begin{tabular}{ccccccc}
\hline \hline Variable & Obs & Mean & Std. Dev. & Min & Max \\
\hline \hline & \multicolumn{7}{c}{ Permanent Innovators } \\
Employment & 197 & 1,326 & 4,539 & 17 & 49,744 \\
Avg. Yearly Employment Growth & 197 & 0.025 & 0.137 & -0.349 & 0.827 \\
& Occasional Innovators & & \\
Employment & 685 & 364 & 1524 & 2 & 37,033 \\
Avg. Yearly Employment Growth & 685 & -0.001 & 0.089 & -0.407 & 0.628 \\
& \multicolumn{7}{c}{ Non-Innovators } & & \\
Employment & 191 & 125 & 361 & 1 & 4,099 \\
Avg. Yearly Employment Growth & 191 & -0.023 & 0.092 & -0.393 & 0.235 \\
\hline \hline
\end{tabular}

Table 2 shows two different employment variables for three groups of firms: firms that reported an innovation for all years in which they were observed (permanent innovators), firms that switched at least once between innovation and no innovation or vice versa (occasional innovators) and firms that never reported an innovation during their observation period (non-innovators). We find significant differences for these three groups. First it seems that mainly the large firms innovate permanently. The mean firm size of permanent innovators is 1,326 , going down to 364 for occasional innovators and 125 for non-innovators. It is also interesting to look at the comparison of the average yearly growth rate of employment during the observation period: Permanent innovators grow with an average yearly growth rate of $2.5 \%$ whereas occasional innovators on average almost stay at the same size and non-innovators shrink with an average yearly growth rate of $2.3 \%$. This can be interpreted as a first descriptive evidence for a positive impact of innovations on employment at the firm level. 


\section{Results}

\subsection{Basic Results}

This section presents the results of our estimations. ${ }^{10}$ In our first result table (Table 3 ) we show the results for simple $\mathrm{AR}(2)$ regressions of the employment variable to compare the different estimation methods presented in Section 2. Because lags of the dependent variable of a higher order than two are not significant, we present the results for the different estimation methods for the AR(2) process only.

Table 3: AR(2) Process of Employment

\begin{tabular}{|c|c|c|c|c|}
\hline & $\begin{array}{c}(1) \\
O L S\end{array}$ & $\begin{array}{l}(2) \\
F E\end{array}$ & $\begin{array}{c}\text { (3) } \\
\text { GMM diff }\end{array}$ & $\begin{array}{c}(4) \\
\text { GMM sys }\end{array}$ \\
\hline Lag Employment & $0.723^{* * *}(0.045)$ & $0.347^{* * *}(0.050)$ & $0.379^{* * *}(0.124)$ & $0.731^{* * *}(0.149)$ \\
\hline 2nd Lag Employment & $0.259^{* * *}(0.046)$ & $0.036 \quad(0.033)$ & $0.096 \quad(0.090)$ & $0.107 \quad(0.077)$ \\
\hline Constant & $0.085^{* * *}(0.019)$ & $3.004^{* * *}(0.213)$ & & $0.784^{*} \quad(0.405)$ \\
\hline Observations & 7536 & 7536 & 6463 & 7536 \\
\hline Number of Firms & 1073 & 1073 & 1073 & 1073 \\
\hline
\end{tabular}

* significant at $10 \%$; ** significant at $5 \%$; *** significant at $1 \%$.

As one can see in Table 3, the coefficients behave exactly as expected. The estimators of the lagged dependent variables add to an estimator of 0.982 for the OLS model in Specification (1), 0.383 in the fixed effects model of Specification (2), 0.475 in the GMM difference model in Specification (3) and 0.838 in the GMM system estimation in Specification (4). This confirms the expected directions of the bias of the lagged dependent variables. In the OLS model the estimates are biased upwards, in the fixed effects and the GMM difference model the estimates are biased downwards. The estimates in the GMM system estimation lie between the upper bound of the OLS model and the lower bound of the fixed effects and the GMM difference model.

Table 4 shows the results of our baseline specifications, where we use the simple product and process innovation dummies as our innovation measures. Specification (5) to (7) differ in the use of dummies for industry sectors and years. Specification (5) shows the results without dummy variables for industry and year, Specification (6) includes year dummies to control for any shocks that are common for all firms. Specification (7)

\footnotetext{
10 The dynamic panel estimations were estimated using the Stata command xtabond2, written by David Roodman (Roodman 2006).
} 
includes year dummies and industry dummies. The choice of the specification only affects the other control variables and has no relevant impact on the estimated effects of the innovation variables. In Specification (5) the sector variables for real hourly wage rate and Gross Value Added (GVA) show both significant effects as expected. The wage rate has a significantly negative effect on employment whereas the GVA as a proxy for demand shows a significantly positive effect. In Specification (6), which includes year dummies, only the GVA remains significant. The significance of the wage rate is taken away in the year dummies. In Specification (7) both the wage rate and the GVA are not significant anymore. Since the year dummies are jointly significant, but sector dummies are not we decide to stick to the specification with year dummies only as the sector effect seems to be captured well by the GVA (Specification (6)).

Table 4: GMM System Estimation Results

\begin{tabular}{|c|c|c|c|}
\hline & (5) & (6) & (7) \\
\hline Lag Employment & $0.744^{* * *}(0.088)$ & $0.743^{* * *}(0.080)$ & $0.679^{* * *}(0.082)$ \\
\hline 2nd Lag Employment & $0.130^{* *}(0.061)$ & $0.139^{* *}(0.055)$ & $0.155^{* * *}(0.056)$ \\
\hline Product Innovation & $-0.004 \quad(0.046)$ & $\begin{array}{ll}-0.001 & (0.039)\end{array} \mid$ & $\begin{array}{ll}-0.008 & (0.041)\end{array}$ \\
\hline Lag Product Innovation & $0.012(0.014)$ & $0.014 \quad(0.013)$ & $0.017 \quad(0.013)$ \\
\hline 2nd Lag Product Innovation & $0.009 \quad(0.010)$ & $0.015^{*}(0.008)$ & $0.017^{* *}(0.008)$ \\
\hline Process Innovation & $0.018 \quad(0.032)$ & $0.034 \quad(0.033)$ & $0.040 \quad(0.037)$ \\
\hline Lag Process Innovation & $0.025^{* *}(0.010)$ & $0.023^{* *}(0.009)$ & $0.023^{* *}(0.010)$ \\
\hline 2nd Lag Process Innovation & $0.015^{* *}(0.008)$ & $0.016^{* *}(0.007)$ & $0.017^{* *}(0.007)$ \\
\hline Real Hourly Wage Rate & $-0.190^{* * *}(0.051)$ & $-0.126 \quad(0.083)$ & $-0.020 \quad(0.110)$ \\
\hline Gross Value Added & $0.050^{* * *}(0.015)$ & $0.047^{* * *}(0.015)$ & $-0.064 \quad(0.069)$ \\
\hline Year Dummies & --- & incl. & incl. \\
\hline Sector Dummies & --- & --- & incl. \\
\hline Constant & $1.290^{* * *}(0.327)$ & $0.949^{* *}(0.462)$ & $1.165^{* *}(0.510)$ \\
\hline Observations & 7536 & 7536 & 7536 \\
\hline Number of Firms & 1073 & 1073 & 1073 \\
\hline Sargan Value (Degrees of Freedom) & $243(205)$ & $192(205)$ & 191 (205) \\
\hline Sargan p-Value & $(0.035)$ & $(0.734)$ & $(0.754)$ \\
\hline $\operatorname{AR}(1)$ & $-2.780^{* * *}$ & $-2.911^{* * *}$ & $-2.779^{* * *}$ \\
\hline AR1 p-Value & $(0.005)$ & $(0.004)$ & $(0.005)$ \\
\hline $\operatorname{AR}(2)$ & -0.640 & -0.863 & -1.199 \\
\hline AR(2) p-Value & $(0.522)$ & $(0.388)$ & $(0.230)$ \\
\hline
\end{tabular}

* significant at $10 \% ;{ }^{* \star}$ significant at $5 \%$; *** significant at $1 \%$. 
In Specifications (6) and (7) test statistics support the validity of our estimations. The Sargan test does not reject our instruments used, the AR(2) test does not reject the null hypothesis of no second-order serial correlation. ${ }^{11} \mathrm{We}$ also tested for the validity of the additional instruments in the GMM system model compared to the GMM difference model as proposed in Blundell and Bond (1998). The difference in Sargan test does not reject the validity of the additional instruments in the GMM system estimation compared to the GMM difference estimation in any of the specifications. ${ }^{12}$

The coefficients of the lagged dependent variables confirm the importance of including these variables. In all three specifications the effect is quite similar. In Specification (6), our preferred model, we find a significant effect of 0.744 for the first lag and a significant effect of 0.130 for the second lag. A test for the sum to be one is rejected, which supports the stability of the model. The size of these coefficients is very stable in all our following regressions. They are also very similar to other studies. Piva and Vivarelli (2005) use only one lag of the dependent variable and find a coefficient of about 0.86 , in van Reenen's (1997) study the sum of two lags varies between 0.4 and 0.8 .

The innovation variables also show significantly positive effects. Before analyzing the results in more detail it is interesting to look at the treatment of the innovation variables. Variables which are not strictly exogenous can be either treated as predetermined or endogenous in the GMM system framework. This distinction defines which instruments are valid. ${ }^{13}$ Since in the model treating innovation as endogenous the set of moment conditions is a strict subset of the set of moment conditions in the model treating innovation as predetermined we can use a difference in Sargan test to test the validity of the additional instruments in the model with predetermined innovation. This test shows that the model treating innovations as predetermined is rejected at the $5 \%$ level $(p-$

\footnotetext{
11 The significant first-order correlation of the errors is induced by first differencing the data. If the errors $\varepsilon_{i, t}$ are i.i.d. with variance $\sigma^{2}$ for the corresponding first differences we get: $E\left(\Delta \varepsilon_{i, t} \Delta \varepsilon_{i, t-1}\right)=-\sigma^{2}$ and $E\left(\Delta \varepsilon_{i, t} \Delta \varepsilon_{i, t-2}\right)=0$. Therefore, we must use the relevant test whether the errors in first differences are $\operatorname{AR}(2)$ or not.

12 The test statistic for our baseline specification (6) is 55.78 with 58 degrees of freedom resulting in a pvalue of 0.558 . Specifications (5) and (7) show qualitatively the same results.

13 If we treat innovation as predetermined we can use variable levels dated from period one up to period $t-1$ as instruments for the first differenced equation in period $t$ and differences from period two up to period $t$ as instruments for the level equation in period $t$. If we treat innovation as endogenous valid instruments stop one year earlier (i.e. at period $t-2$ for the first differenced equation and at $t-1$ for the levels equation in period $t$; cf. Section 2).
} 
Value $=0.044)$. Thus, in the following specifications we will treat innovation as endogenous.

Next we will turn to the analysis of the innovation variables. As for product innovations we can see that only the second lag of product innovations shows a weakly significant positive effect on employment. This result is surprising since most studies find a positive effect for product innovation and a positive effect would be expected according to the direct effect from theory (cf. Section 1). Our explanation for this result is that the definition of innovation in the Ifo Innovation Survey might be responsible for this result as it includes also very small innovations. We will test in later specifications how the more important innovations affect employment.

Process innovations, however, show a clearly positive effect on employment. Again the lagged variables show significantly positive effects, but as for process innovations these are the first and the second lag. Also, the estimated effects are higher than those for product innovations. This result supports the hypothesis that the indirect effects of process innovations are present and firms pass on the productivity gains to lower prices and thus can increase demand and employment. This significantly positive effect was not clear from a theoretical point of view, but is in line with some previous studies (e.g. Blanchflower and Burgess 1999 or Greenan and Guellec 2000). In addition, it is interesting that we find a higher effect for process innovations than for product innovations. This was only found in few studies (e.g. Greenan and Guellec 2000, Lachenmaier and Rottmann 2006).

We also carried out different tests for joint significance. Testing for joint significance in Specification (6) for all product innovation variables does also not show a significant effect whereas process innovations are jointly significant at the $5 \%$ level. Testing for joint significance for product and process innovations in the different lags shows that the contemporaneous innovation variables are jointly insignificant whereas both the first and second lag are jointly significant at the $5 \%$ level.

As mentioned in Section 3.2 we had to restrict our estimation sample to firms which have answered at least six consecutive years. Since this restriction leads to a larger share of large firms which stay in the sample, we tested our results for the robustness regarding extreme outliers. We dropped the lowest and the largest percentile of firms in terms of employees. It turns out that our results are not very sensitive to the presence of outliers. Regression results are very similar to the whole sample. Especially the coefficients of the innovation variables remain almost unchanged. We also tested deeper lags of innovations. But these lags were not significant in any specification. 
We also conduct more robustness tests by using different lag structures as instruments. In our standard specifications we use three lags as instruments in the differenced equation, i.e. for an endogenous explanatory variable in the first-differenced equation $\left(\Delta X_{t}\right)$, we use $X_{i, t-2}, X_{i, t-3}$ and $X_{i, t-4}$. As tests for robustness we estimate specifications, in which we use two to five lags und a specification where we use all available valid lags as instruments. In specifications with two to five lags we find no qualitative and only minor quantitative changes in the coefficients. In specifications using all available valid lags as instruments, the coefficient of the second lag of product innovations sometimes gets insignificant, which is due to an increase in the standard error whereas the coefficient does hardly change. The significantly positive effect of process innovations remains. ${ }^{14}$

\subsection{Results Using Different Innovation Measures}

In Table 5 we use different innovation output measures. In Specification (8) we replace the simple innovation variables by those for which the firms responded that R\&D was necessary. But, the results for both types of innovation are quite similar to those of Specification (6) with the simple innovation indicators. Again, for product innovations only the second lag shows a significant effect, whereas for process innovations the first and the second lag show significant effects. Also, as for the size of the effects, results are very similar to the estimates before. Joint significance test also show the known results from Specification (6). Product innovations are jointly insignificant, process innovations are jointly significant. The contemporaneous variables are jointly insignificant whereas both first (at 5\% level) and second lags (at 1\% level) are jointly significant.

Specification (9) uses those innovations which went along with patent applications. We have to keep in mind that the number of firms with process innovations with patent applications is very low (see Table 1), so these results should only be interpreted with caution. As we can see from the results, the standard errors for process innovations are indeed quite high which might be a reason for not finding significant effects. For product innovations we find in this specification highly positive and significant effects. Especially the contemporaneous variable shows a high effect on employment. This confirms our hypothesis that the high costs for patent applications are only invested for very promising innovations for which high returns are expected. Joint significance tests in this specification show no significance for process innovations. Product innovations show a

14 Detailed results are not shown, but are available from the authors upon request. 
jointly significant effect at the $1 \%$ level. Test statistics support the validity of our results in all specifications.

Table 5: Further GMM System Estimation Results

\begin{tabular}{|c|c|c|}
\hline & $(8)$ & (9) \\
\hline Lag Employment & $0.780^{* * *}(0.072)$ & $0.670^{* * *}(0.067)$ \\
\hline 2nd Lag Employment & $0.121^{* *}(0.050)$ & $0.185^{* * *}(0.045)$ \\
\hline Product Innovation (R\&D) & $-0.004 \quad(0.046)$ & --- \\
\hline Lag Product Innovation (R\&D) & $0.012(0.018)$ & --- \\
\hline 2nd Lag Product Innovation (R\&D) & $0.022^{*}(0.013)$ & --- \\
\hline Process Innovation (R\&D) & $-0.016 \quad(0.044)$ & --- \\
\hline Lag Process Innovation (R\&D) & $0.033^{* *}(0.013)$ & --- \\
\hline 2nd Lag Process Innovation (R\&D) & $0.029^{* * *}(0.010)$ & --- \\
\hline Product Innovation (Patent) & --- & $0.210^{* * *}(0.057)$ \\
\hline Lag Product Innovation (Patent) & --- & $0.007 \quad(0.020)$ \\
\hline 2nd Lag Product Innovation (Patent) & --- & $0.036^{* * *}(0.014)$ \\
\hline Process Innovation (Patent) & --- & $0.100 \quad(0.127)$ \\
\hline Lag Process Innovation (Patent) & --- & $0.051 \quad(0.054)$ \\
\hline 2nd Lag Process Innovation (Patent) & --- & $0.099 \quad(0.076)$ \\
\hline Real Hourly Wage Rate & $-0.029 \quad(0.075)$ & $-0.039 \quad(0.114)$ \\
\hline Gross Value Added & $0.036^{* * *}(0.012)$ & $0.037^{* * *}(0.014)$ \\
\hline Year Dummies & incl. & incl. \\
\hline Constant & $0.430 \quad(0.410)$ & 0.672 \\
\hline Observations & 6963 & 6963 \\
\hline Number of Firms & 1059 & 1059 \\
\hline Sargan Value (Degrees of Freedom) & $192(205)$ & $183(205)$ \\
\hline Sargan p-Value & $(0.741)$ & $(0.866)$ \\
\hline $\operatorname{AR}(1)$ & $-2.933^{* * *}$ & $-2.942^{* * *}$ \\
\hline AR1 p-Value & $(0.003)$ & $(0.003)$ \\
\hline $\operatorname{AR}(2)$ & -0.251 & -1.625 \\
\hline $\operatorname{AR}(2) \mathrm{p}$-Value & $(0.802)$ & $(0.104)$ \\
\hline
\end{tabular}

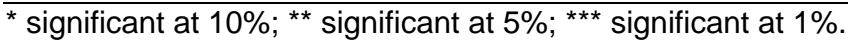

In Table 6 we replace the innovation output variables used so far by variables which measure the input into the innovation process. Results are shown for two different measures of innovation input. Unfortunately, not all firms respond always to the question relating to innovation expenditure. So, our sample is reduced to 4,448 observations from 
690 firms. When using innovation expenditure as explanatory variable one practical problem arises. Ideally, we would like to include innovation expenditure also in log values. However, simply taking the log would lead to the loss of all firms which have zero innovation expenditure, i.e. all non-innovators. Thus we present two different specifications. In Specification (10) we replaced the original innovation expenditure by one plus the original value. This leads to a value of zero for non-innovators after taking the logarithm. This method is sometimes used in such cases, but does not distinguish anymore between innovators and non-innovators by replacing zero innovation expenditure with low positive values. $^{15}$

Table 6: GMM System Results Using Innovation Input Variables

\begin{tabular}{|c|c|c|c|c|}
\hline \multirow[b]{2}{*}{ Lag Employment } & \multicolumn{2}{|c|}{$(10)$} & \multicolumn{2}{|c|}{$(11)$} \\
\hline & $0.833^{* * *}$ & $(0.075)$ & $0.889^{* * *}$ & $(0.066)$ \\
\hline 2nd Lag Employment & 0.087 & $(0.063)$ & 0.062 & $(0.059)$ \\
\hline Innovation Expenditure & 0.010 & $(0.009)$ & --- & \\
\hline Lag Innovation Expenditure & 0.002 & $(0.004)$ & --- & \\
\hline 2nd Lag Innovation Expenditure & $0.006^{* *}$ & $(0.002)$ & --- & \\
\hline Innovation Expenditure (Dummy) & --- & & -0.004 & $(0.015)$ \\
\hline Lag Innovation Expenditure (Dummy) & --- & & 0.007 & $(0.015)$ \\
\hline 2nd Lag Innovation Expenditure (Dummy) & --- & & $0.031^{* * *}$ & $(0.011)$ \\
\hline Real Hourly Wage Rate & -0.064 & $(0.108)$ & -0.013 & $(0.111)$ \\
\hline Gross Value Added & $0.031^{* *}$ & $(0.014)$ & $0.033^{* *}$ & $(0.013)$ \\
\hline Year Dummies & Incl. & & incl. & \\
\hline Constant & 0.499 & $(0.549)$ & 0.160 & $(0.540)$ \\
\hline Observations & 4448 & & 4448 & \\
\hline Number of Firms & 690 & & 690 & \\
\hline Sargan Value (Degrees of Freedom) & $140(134)$ & & $165(152)$ & \\
\hline Sargan p-Value & $(0.336)$ & & $(0.226)$ & \\
\hline $\operatorname{AR}(1)$ & $-4.857^{* * *}$ & & $-5.325^{* * *}$ & \\
\hline AR1 p-Value & $(0.000)$ & & $(0.000)$ & \\
\hline $\operatorname{AR}(2)$ & -1.463 & & -1.189 & \\
\hline
\end{tabular}

$15 \mathrm{We}$ also tested other values than one. We used $0.01,0.1$ and the minimum value for this variable of other firms. However, results are very robust to the choice of the value that we use for replacing. 
* significant at 10\%; ** significant at 5\%; ${ }^{\star \star \star}$ significant at $1 \%$. 
Results show a significantly positive effect for the second lag of innovation expenditure. This is no surprise since we would actually expect a longer time lag between the innovation expenditure and its effect on employment than for innovation output measures and their effects. It can take some time from the beginning of an innovation to the implementation in the firm or the introduction to market. In contrast to Specification (10) we concentrate on the distinction between firms with and without innovation expenditure in Specification (11). In this specification we include a dummy variable which is one for all firms that reported any positive innovation expenditure and zero otherwise. Again, we find a significantly positive effect of the second lag.

So, to sum up, almost all of our innovation measures show a significantly positive effect on employment. Surprisingly, this effect is higher for process innovation than for product innovations. An exception of this pattern are product innovations for which patent applications were filed, which show a very high and significantly positive effect. As for the input variables, the estimations also lead to significantly positive effects. Innovation output variables usually show their effects faster than the innovation input variable, which is innovation expenditure.

\section{Conclusions}

The effect of innovation on employment remains unclear in theoretical contributions. This has given reasons to address this question empirically. With an increasing data availability it is possible to estimate the effects at the firm level - the level at which the decision to innovate or not takes place. Our uniquely long panel data set, covering more than 20 years, offers detailed information about the innovation behavior of German manufacturing firms. We have data available for innovation output and innovation input measures. Innovation output is measured by information about innovations introduced or implemented. Innovation input is measured by innovation expenditure. As for innovation output, we can distinguish between product and process innovations, as it is proposed by theoretical contributions. In addition, the innovation output indicators can further be divided into several categories reflecting the importance of innovations.

To control for unobserved firm heterogeneity, endogeneity of innovation with respect to employment and dynamics we employ dynamic panel analyses. The effect of the lagged dependent variable is almost stable across all specifications. The effects of innovation on employment are positive and robust to several specifications. The effect for process 
innovation tends to be higher than the effect for product innovation. We find significant effects mostly for the first or second lag, except for product innovations with patent applications which also have a contemporaneous effect on employment. Innovation inputs are also significantly positive. For this measure we only find significant effects for the second lag of the variable. This gives further support to our innovation variables as we find a longer lag for the effect of innovation input on employment than for innovation output. 


\section{References}

Anderson, T. W. and Hsiao, C. (1982), 'Formulation and estimation of dynamic models using panel data', Journal of Econometrics 18, 47-82.

Arellano, M. und Bond, S. R. (1991) 'Some Tests of Specification for Panel Data: Monte Carlo Evidence and an Application to Employment Equations', Review of Economic Studies 58, 277-297.

Blanchflower, D. and Burgess, S. (1999) 'New technology and jobs: comparative evidence from a two country study', Economics of Innovation and New Technology, 6, forthcoming.

Blundell, R. and Bond, S. (1998) 'Initial conditions and moment restrictions in dynamic panel data models', Journal of Econometrics 87, 115-143.

Bond, S. (2002) 'Dynamic panel data models: a guide to micro data methods and practice', Portugese Economic Journal 1, 141-162.

Brouwer, E., Kleinknecht, A. and Reijnen, J. (1993) 'Employment growth and innovation at the firm level: an empirical study', Journal of Evolutionary Economics, 3, 153-159.

Chennells, L. and Van Reenen, J. (2002) 'The effects of technical change on skills, wages and employment: A survey of the micro-econometric evidence'. In L'Horty, Y., Greenan, N., and Mairesse, J. (eds.) Productivity, inequality and the digital economy, MIT Press, $175-225$.

Entorf, H. and Pohlmeir, W.(1991) 'Employment, innovation and export activity', in Florens, J. et al. (eds.) Microeconometrics: surveys and applications, Oxford: Basil Blackwell.

Greenan, N. and Guellec, D. (1997) 'Technological innovation and employment reallocation', INSEE mimeo.

Hamermesh, D. D. (1993) Labor demand. Princeton University Press.

Harrison, R. , Jaumandreu, J. Mairesse, J. and Peters, B. (2005): 'Does innovation stimulate employment? A firm-level analysis using comparable microdata from four European countries,' available at http://www.eco.uc3m.es/IEEF/documentpapers.html.

Holtz-Eakin, D., Newey, W. and Rosen, H. (1988) 'Estimating vector autoregressions with panel data', Econometrica 56, 1371-1396.

Jaumandreu, J. (2003) 'Does innovation spur employment? A firm-level analysis using Spanish CIS data', mimeo, university Carlos III de Madrid.

Katsoulacos, Y. (1986) The Employment Effect of Technical Change, Oxford: OUP.

Klette, T. and Førre, S. (1998) 'Innovation and job creation in a small open economy: evidence from Norwegian manufacturing plants 1982-92', Economics of Innovation and New Technology, 5, 247-272. 
Lachenmaier, S. and Rottmann, H. (2006) 'Employment effects of innovation at the firm level', Ifo Working Papers 27, Munich.

Lachenmaier, S and Wößmann, L. (2004) 'Does innovation cause exports? Evidence from exogenous innovation impulses and obstacles using German micro data', Oxford Economic Papers 58 (2), 317-350.

OECD and Eurostat (2005) Oslo Manual. Guidelines for collecting and interpreting innovation data. $3^{\text {rd }}$ edition. OECD.

Peters, B. (2004) Employment effects of different innovation activities: Microeconometric evidence. ZEW Discussion Paper 04-73. ZEW Mannheim.

Petit, P. (1995) Employment and Technological Change. In Stoneman, P. (ed) Handbook of the Economics of Innovation and Technological Change. Blackwell Publishing. Oxford and Cambridge.

Piva, M. and Vivarelli, M. (2004) 'Technological change and employment: some micro evidence from Italy', Applied Economics Letters 11, 373-376.

Piva, M. and Vivarelli, M. (2005) 'Innovation and employment: Evidence from Italian microdata', Journal of Economics 86, 65-83.

Roodman, D. (2006) 'How to do xtabond2: An Introduction to 'Difference' and 'System' GMM in Stata', Center for Global Development Working Paper 103, Washington.

Rottmann, H. and Ruschinski, M. (1998) 'The labour demand and the innovation behaviour of firms. An empirical investigation for West German manufacturing firms' Jahrbücher für Nationalökonomie und Statistik, 217, 741-752.

Smolny, W. (1998) 'Innovations, prices and employment: a theoretical model and empirical application for West German manufacturing firms', Journal of Industrial Economics, XLVI(3), 359-382.

Stoneman, P. (1983) The economic analysis of technological change. Oxford: Oxford University Press.

Van Reenen, J. (1997) 'Technological innovation and employment in a panel of British manufacturing firms', Journal of Labor Economics , 15(2), 255-284.

Zimmerman, K. (1991) 'The employment consequences of technological advance: demand and labour costs in 16 German Industries', Empirical Economics, 16, 253-266. 


\section{APPENDIX}

Table A1: Comparison of Estimation Sample and Original Sample

\begin{tabular}{|c|c|c|c|c|c|c|c|c|c|c|}
\hline \multirow[b]{2}{*}{ Variable } & \multirow[b]{2}{*}{ Obs } & \multicolumn{4}{|c|}{ Original Sample } & \multicolumn{5}{|c|}{ Estimation Sample } \\
\hline & & Mean & p25 & Median & p75 & Obs & Mean & p25 & Median & p75 \\
\hline Employment & 31,885 & 445 & 39 & 100 & 275 & 7536 & 654 & 45 & 129 & 353 \\
\hline Innovation & 31,420 & 0.494 & & & & 7536 & 0.513 & & & \\
\hline Product Innovation & 31,420 & 0.403 & & & & 7536 & 0.420 & & & \\
\hline Process Innovation & 31,420 & 0.315 & & & & 7536 & 0.335 & & & \\
\hline Product Innovation (R\&D) & 30,995 & 0.329 & & & & 7475 & 0.348 & & & \\
\hline Process Innovation (R\&D) & 30,488 & 0.195 & & & & 7337 & 0.220 & & & \\
\hline Product Innovation (Patents) & 30,995 & 0.190 & & & & 7475 & 0.196 & & & \\
\hline Process Innovation (Patents) & 30,488 & 0.023 & & & & 7337 & 0.026 & & & \\
\hline Innovation Expenditure (Dummy) & 24,978 & 0.512 & & & & 4448 & 0.473 & & & \\
\hline Innovation Expenditure & 24,978 & 3,343 & 0 & 11.3 & 466 & 4448 & 8,883 & 0 & 0 & 438 \\
\hline
\end{tabular}

Notes: $\mathrm{p} 25: 25^{\text {th }}$ percentile, $\mathrm{p} 75: 75^{\text {th }}$ percentile. 
Table A2: Distribution of firms in NACE 2digit Sector and Size Classes

\begin{tabular}{|c|c|c|c|c|c|c|c|}
\hline & & $\begin{array}{c}-49 \\
\text { employees }\end{array}$ & \begin{tabular}{|c|}
$50-199$ \\
employees
\end{tabular} & \begin{tabular}{|l|}
$200-499$ \\
employees
\end{tabular} & $\begin{array}{c}\text { 500-999 } \\
\text { employees }\end{array}$ & \begin{tabular}{|c|}
$1000+$ \\
employees
\end{tabular} & Total \\
\hline 15 & M.o. food products and beverages & $29 / 237$ & $38 / 160$ & $12 / 50$ & $5 / 34$ & $2 / 13$ & $86 / 494$ \\
\hline 16 & M.o. tobacco products & $2 / 6$ & $0 / 4$ & $1 / 4$ & $0 / 0$ & $1 / 3$ & $4 / 17$ \\
\hline 17 & M.o. textiles & $10 / 81$ & $16 / 153$ & $9 / 74$ & $1 / 19$ & $1 / 6$ & $37 / 333$ \\
\hline 18 & M.o. wearing apparel & $14 / 91$ & $10 / 77$ & $5 / 21$ & $3 / 8$ & $1 / 4$ & $33 / 201$ \\
\hline 19 & Leather & $4 / 49$ & $7 / 61$ & $3 / 15$ & $0 / 2$ & $0 / 0$ & $14 / 127$ \\
\hline 20 & M.o. wood and wood products & $43 / 232$ & $14 / 82$ & $3 / 19$ & $0 / 5$ & $0 / 2$ & $60 / 340$ \\
\hline 21 & M.o. pulp, paper & $13 / 104$ & $22 / 116$ & $9 / 53$ & $5 / 22$ & $3 / 12$ & $52 / 307$ \\
\hline 22 & Publishing, printing & $29 / 201$ & $39 / 176$ & $13 / 49$ & $6 / 17$ & $3 / 6$ & $90 / 449$ \\
\hline 23 & M.o. coke, fuel & $0 / 2$ & $0 / 1$ & $0 / 3$ & $0 / 5$ & $2 / 7$ & $2 / 18$ \\
\hline 24 & M.o. chemicals & $8 / 82$ & $7 / 62$ & $5 / 27$ & $2 / 9$ & $3 / 9$ & $25 / 189$ \\
\hline 25 & M.o. rubber, plastic products & $20 / 231$ & $27 / 207$ & $8 / 62$ & $7 / 21$ & $3 / 16$ & $65 / 537$ \\
\hline 26 & M.o. no-metallic mineral products & $23 / 192$ & $33 / 151$ & $29 / 75$ & $6 / 30$ & $3 / 18$ & $94 / 466$ \\
\hline 27 & M.o. basic metals & $3 / 22$ & $8 / 38$ & $3 / 21$ & $5 / 20$ & $1 / 12$ & $20 / 113$ \\
\hline 28 & M.o. fabricated metal products & $28 / 246$ & $41 / 237$ & $18 / 98$ & $6 / 38$ & $3 / 17$ & $96 / 636$ \\
\hline 29 & M.o. machinery and equipment & $15 / 266$ & $42 / 439$ & $41 / 254$ & $32 / 116$ & $22 / 109$ & $152 / 1184$ \\
\hline 30 & M.o. office machinery and computers & $0 / 5$ & $0 / 3$ & $0 / 4$ & $0 / 0$ & $1 / 6$ & $1 / 18$ \\
\hline 31 & M.o. electrical machinery & $10 / 95$ & $15 / 141$ & $17 / 77$ & $7 / 40$ & $12 / 28$ & $61 / 381$ \\
\hline 32 & M.o. radio, TV & $2 / 24$ & $6 / 42$ & $4 / 35$ & $7 / 19$ & $3 / 32$ & $22 / 152$ \\
\hline 33 & M.o. medical and optical instruments & $14 / 110$ & $19 / 106$ & $7 / 46$ & $9 / 17$ & $3 / 19$ & $52 / 298$ \\
\hline 34 & M.o. motor vehicles & $3 / 21$ & $5 / 33$ & $2 / 20$ & $4 / 12$ & $15 / 38$ & $29 / 124$ \\
\hline 35 & M.o. other transport equipment & $0 / 5$ & $2 / 13$ & $2 / 3$ & $2 / 6$ & $4 / 11$ & $10 / 38$ \\
\hline 36 & M.o. furniture, manufacturing n.e.c. & $19 / 134$ & $27 / 164$ & $17 / 69$ & $4 / 21$ & $1 / 7$ & $68 / 395$ \\
\hline & Total & $289 / 2436$ & $378 / 2466$ & $208 / 1079$ & $111 / 461$ & $87 / 375$ & $1073 / 6817$ \\
\hline
\end{tabular}

Notes: Numbers represent the number of firms in estimation sample / original sample. 


\section{CESifo Working Paper Series}

(for full list see www.cesifo-group.de)

1948 C. Mirjam van Praag and Bernard M. S. van Praag, The Benefits of Being Economics Professor A (and not Z), March 2007

1949 Astrid Hopfensitz and Frans van Winden, Dynamic Choice, Independence and Emotions, March 2007

1950 Guglielmo Maria Caporale and Luis A. Gil-Alana, A Multivariate Long-Memory Model with Structural Breaks, March 2007

1951 Mattias Ganslandt and Keith E. Maskus, Wholesale Price Discrimination and Parallel Imports, March 2007

1952 Michela Redoano, Fiscal Interactions Among European Countries. Does the EU Matter?, March 2007

1953 Stefan C. Wolter, Rémy Hübschi and Matthias Müller, Push or Pull? An Empirical Analysis of the Demand for Individual Project Grants from the Swiss National Science Foundation, March 2007

1954 Scott Alan Carson, African-American and White Inequality in the American South: Evidence from the $19^{\text {th }}$ Century Missouri State Prison, March 2007

1955 Peter Egger, Marko Koethenbuerger and Michael Smart, Do Fiscal Transfers Alleviate Business Tax Competition? Evidence from Germany, March 2007

1956 Panu Poutvaara and Lars-H. R. Siemers, Smoking and Social Interaction, March 2007

1957 Stephan Danninger and Fred Joutz, What Explains Germany's Rebounding Export Market Share?, March 2007

1958 Stefan Krasa and Mattias Polborn, Majority-efficiency and Competition-efficiency in a Binary Policy Model, March 2007

1959 Thiess Buettner and Georg Wamser, Intercompany Loans and Profit Shifting Evidence from Company-Level Data, March 2007

1960 Per Pettersson-Lidbom and Mikael Priks, Behavior under Social Pressure: Empty Italian Stadiums and Referee Bias, April 2007

1961 Balázs Égert and Carol S. Leonard, Dutch Disease Scare in Kazakhstan: Is it real?, April 2007

1962 Paul De Grauwe and Pablo Rovira Kaltwasser, Modeling Optimism and Pessimism in the Foreign Exchange Market, April 2007 
1963 Volker Grossmann and Thomas M. Steger, Anti-Competitive Conduct, In-House R\&D, and Growth, April 2007

1964 Steven Brakman and Charles van Marrewijk, It's a Big World After All, April 2007

1965 Mauro Ghinamo, Paolo M. Panteghini and Federico Revelli, FDI Determination and Corporate Tax Competition in a Volatile World, April 2007

1966 Inés Macho-Stadler and David Pérez-Castrillo, Optimal Monitoring to Implement Clean Technologies when Pollution is Random, April 2007

1967 Thomas Eichner and Ruediger Pethig, Efficient $\mathrm{CO}_{2}$ Emissions Control with National Emissions Taxes and International Emissions Trading, April 2007

1968 Michela Redoano, Does Centralization Affect the Number and Size of Lobbies?, April 2007

1969 Christian Gollier, Intergenerational Risk-Sharing and Risk-Taking of a Pension Fund, April 2007

1970 Swapan K. Bhattacharya and Biswa N. Bhattacharyay, Gains and Losses of India-China Trade Cooperation - a Gravity Model Impact Analysis, April 2007

1971 Gerhard Illing, Financial Stability and Monetary Policy - A Framework, April 2007

1972 Rainald Borck and Matthias Wrede, Commuting Subsidies with two Transport Modes, April 2007

1973 Frederick van der Ploeg, Prudent Budgetary Policy: Political Economy of Precautionary Taxation, April 2007

1974 Ben J. Heijdra and Ward E. Romp, Retirement, Pensions, and Ageing, April 2007

1975 Scott Alan Carson, Health during Industrialization: Evidence from the $19^{\text {th }}$ Century Pennsylvania State Prison System, April 2007

1976 Andreas Haufler and Ian Wooton, Competition for Firms in an Oligopolistic Industry: Do Firms or Countries Have to Pay?, April 2007

1977 Eckhard Janeba, Exports, Unemployment and the Welfare State, April 2007

1978 Gernot Doppelhofer and Melvyn Weeks, Jointness of Growth Determinants, April 2007

1979 Edith Sand and Assaf Razin, The Role of Immigration in Sustaining the Social Security System: A Political Economy Approach, April 2007

1980 Marco Pagano and Giovanni Immordino, Optimal Regulation of Auditing, May 2007

1981 Ludger Woessmann, Fundamental Determinants of School Efficiency and Equity: German States as a Microcosm for OECD Countries, May 2007 
1982 Bas Jacobs, Real Options and Human Capital Investment, May 2007

1983 Steinar Holden and Fredrik Wulfsberg, Are Real Wages Rigid Downwards?, May 2007

1984 Cheng Hsiao, M. Hashem Pesaran and Andreas Pick, Diagnostic Tests of Cross Section Independence for Nonlinear Panel Data Models, May 2007

1985 Luis Otávio Façanha and Marcelo Resende, Hierarchical Structure in Brazilian Industrial Firms: An Econometric Study, May 2007

1986 Ondřej Schneider, The EU Budget Dispute - A Blessing in Disguise?, May2007

1987 Sascha O. Becker and Ludger Woessmann, Was Weber Wrong? A Human Capital Theory of Protestant Economic History, May 2007

1988 Erkki Koskela and Rune Stenbacka, Equilibrium Unemployment with Outsourcing and Wage Solidarity under Labour Market Imperfections, May 2007

1989 Guglielmo Maria Caporale, Juncal Cunado and Luis A. Gil-Alana, Deterministic versus Stochastic Seasonal Fractional Integration and Structural Breaks, May 2007

1990 Cláudia Costa Storti and Paul De Grauwe, Globalization and the Price Decline of Illicit Drugs, May 2007

1991 Thomas Eichner and Ruediger Pethig, Pricing the Ecosystem and Taxing Ecosystem Services: A General Equilibrium Approach, May 2007

1992 Wladimir Raymond, Pierre Mohnen, Franz Palm and Sybrand Schim van der Loeff, The Behavior of the Maximum Likelihood Estimator of Dynamic Panel Data Sample Selection Models, May 2007

1993 Fahad Khalil, Jacques Lawarrée and Sungho Yun, Bribery vs. Extortion: Allowing the Lesser of two Evils, May 2007

1994 Thorvaldur Gylfason, The International Economics of Natural Resources and Growth, May 2007

1995 Catherine Roux and Thomas von Ungern-Sternberg, Leniency Programs in a Multimarket Setting: Amnesty Plus and Penalty Plus, May 2007

1996 J. Atsu Amegashie, Bazoumana Ouattara and Eric Strobl, Moral Hazard and the Composition of Transfers: Theory with an Application to Foreign Aid, May 2007

1997 Wolfgang Buchholz and Wolfgang Peters, Equal Sacrifice and Fair Burden Sharing in a Public Goods Economy, May 2007

1998 Robert S. Chirinko and Debdulal Mallick, The Fisher/Cobb-Douglas Paradox, Factor Shares, and Cointegration, May 2007

1999 Petra M. Geraats, Political Pressures and Monetary Mystique, May 2007 
2000 Hartmut Egger and Udo Kreickemeier, Firm Heterogeneity and the Labour Market Effects of Trade Liberalisation, May 2007

2001 Andreas Freytag and Friedrich Schneider, Monetary Commitment, Institutional Constraints and Inflation: Empirical Evidence for OECD Countries since the 1970s, May 2007

2002 Niclas Berggren, Henrik Jordahl and Panu Poutvaara, The Looks of a Winner: Beauty, Gender, and Electoral Success, May 2007

2003 Tomer Blumkin, Yoram Margalioth and Efraim Sadka, Incorporating Affirmative Action into the Welfare State, May 2007

2004 Harrie A. A. Verbon, Migrating Football Players, Transfer Fees and Migration Controls, May 2007

2005 Helmuth Cremer, Jean-Marie Lozachmeur and Pierre Pestieau, Income Taxation of Couples and the Tax Unit Choice, May 2007

2006 Michele Moretto and Paolo M. Panteghini, Preemption, Start-Up Decisions and the Firms' Capital Structure, May 2007

2007 Andreas Schäfer and Thomas M. Steger, Macroeconomic Consequences of Distributional Conflicts, May 2007

2008 Mikael Priks, Judiciaries in Corrupt Societies, June 2007

2009 Steinar Holden and Fredrik Wulfsberg, Downward Nominal Wage Rigidity in the OECD, June 2007

2010 Emmanuel Dhyne, Catherine Fuss, Hashem Pesaran and Patrick Sevestre, Lumpy Price Adjustments: A Microeconometric Analysis, June 2007

2011 Paul Belleflamme and Eric Toulemonde, Negative Intra-Group Externalities in TwoSided Markets, June 2007

2012 Carlos Alós-Ferrer, Georg Kirchsteiger and Markus Walzl, On the Evolution of Market Institutions: The Platform Design Paradox, June 2007

2013 Axel Dreher and Martin Gassebner, Greasing the Wheels of Entrepreneurship? The Impact of Regulations and Corruption on Firm Entry, June 2007

2014 Dominique Demougin and Claude Fluet, Rules of Proof, Courts, and Incentives, June 2007

2015 Stefan Lachenmaier and Horst Rottmann, Effects of Innovation on Employment: A Dynamic Panel Analysis, June 2007 